\title{
THE ATTITUDE OF UNDERGRADUATES TOWARDS E-LEARNING CONSIDERING EDUCATIONAL AND TECHNICAL CHALLENGES AND REQUIREMENTS IN KUWAITI APPLIED COLLEGES
}

\author{
Hamed Alsahou $\left(\mathbb{D}\right.$, Zainab Abbas ${ }^{(D)}$, Ali Alfayly $(\mathbb{D}$ \\ College of Basic Education (Kuwait) \\ dr.alsahou@hotmail.com,dr.zaenab@gmail.com,ah.alfayly@paaet.edu.kw
}

Received June 2021

Accepted September 2021

\begin{abstract}
Digital learning has become one of the constituent elements of higher education in many countries. E-learning platforms provides remarkable opportunities to creatively overcome many problems of traditional learning approaches. Nevertheless, E-learning is not flawless, where there are many educational and technical difficulties of implementing online learning in higher education, especially when higher education stands on applied learning. The current study aims to explore undergraduates' attitudes towards E-learning in applied colleges. It also seeks to expose the most central educational and technical challenges of e-learning. Moreover, it drives to define the educational and technical requirements for ensuring quality e-learning. the research sample consisted of 1650 undergraduates and 37 interviewees who are drawn from five applied colleges in Kuwait (the College of Basic Education, the College of Technological Studies, the College of Business Studies, the College of Health Science, and the College of Nursing). The research design is based on mixed methods (questionnaire and focus groups). The findings revealed that students held neutral attitudes towards e-learning, while the educational and technical challenges are high concerns. Educational challenges and requirements highlighted several themes including instructional support, progress valuation, self-study skills, attention span, interactivity, and class size. Meanwhile, the technical challenges include poor internet connectivity, IT support, LMS interface, training courses. Then, the findings are discussed to draw recommendations and implications.
\end{abstract}

Keywords - E-learning, Educational challenges, Technical challenges, Applied Colleges, Kuwait.

\section{To cite this article:}

Alsahou, H., Abbas, Z., \& Alfayly, A. (2022). The attitude of undergraduates towards E-learning considering educational and technical challenges and requirements in Kuwaiti Applied Colleges. Journal of Technology and Science Education, 12(1), 33-49. https://doi.org/10.3926/jotse.1358

\section{Introduction}

The outbreak of the COVID-19 pandemic has catalyzed the adoption of E-learning in many educational contexts in Kuwait and across the globe. However, this adoption has been met with its fair share of challenges that have limited the effectiveness of the method. Various studies have looked at these challenges that have limited the effectiveness of E-learning outcomes. Some of these studies have revealed challenges that are specifically related to students. Teymori and Fardin (2020) notes that students 
are discouraged from using the E-learning platform whenever they feel that their learning is not spontaneously supported by the instructors who are available to answer their questions and clarify concepts that they are teaching. Alateeq, Aljhani and Eesa (2020) established that students were limited whenever the content that is shared on the eLearning platform has not been developed in a manner that is meaningful to the student's context.

Adnan and Anwar (2020) found that some learners were biased against the E-learning platforms; Mpungose (2020) found that e-learners in Kuwait experienced technical difficulties in using E-learning platforms a problem that is complicated by poor interface designs of the E-learning applications. The students, in this case, may find trouble in logging in, findings learning resources, or giving some feedback to their instructors. In another study, Okereke, Williams, Emmanuella, Ashinedu and Mairaj, (2020) found that Students in remote areas where internet connectivity is poor or unavailable are unable to keep track of their counterparts who live in better-connected areas, a factor that has led to educational inequalities.

The studies also revealed that there were challenges that specifically affected the effectiveness of instructors to use E-learning platforms to disseminate knowledge during the spread of coronavirus. Suryaman, Cahyono, Muliansyah, Bustani, Suryani and Fahlevi (2020) found that instructors were grappling with evaluation challenges in E-learning contexts which were characterized by inconsistencies between the learning and teaching strategies, unethical practices by the students characterized by cheating, and restrictions in terms of the evaluation methods that are available for instructors. According to Teymori and Fardin (2020), the implementation of E-learning has also proved problematic in institutions where there is limited or nonexistent technical and administrative support, whereby the instructors are left on their own to grapple with the various challenges that they encounter during the delivery of their instructions.

Okereke et al. (2020) established that E-learning platform limits the control of the instructors over their students who may log in but engage in other activities that are unrelated to learning. The learning environments are also prone to frequent interruption either due to technical failures or third-party interruptions, which the instructors may have no control over. There are instances where instructors have resisted the change demanded by their institutions to teach students through E-learning platforms, slowing down the learning process as they come to terms or slowly learn the required pedagogies.

The infrastructural challenges experienced in E-learning used during the pandemic were characterized by organizational and technological preparedness. According to Unger and Meiran (2020) whereas the developed platform may be effective it may not be used to the benefit of both instructors and students in cases where either or both parties are ICT illiterate. In this case, it takes a steep learning curve before they begin to reap the benefits of e-learning. Mishraa, Guptab and Shreeb (2020) established that some of the institutional issues include inadequate management support, the lack of strategic direction and planning, and lack of appropriate content development and assessment. Murphy (2020) also found that the institutional factors also included inadequate methodological models for e-learning, the lack of resources, and in some cases a missing E-learning curriculum. This makes it difficult for the instructor to effectively impart knowledge and for the student to make most of their online lessons.

In another study, Koçoğlu and Tekdal (2020) found that the lack of institutional support, lack of adequate training for the instructors, the lack of adequate ICT infrastructure, and the low penetration of internet coverage were some of the notable limitations to E-learning during the pandemic. Suryaman et al. (2020) concurred that technological issues included underdeveloped infrastructure, unstable internet connectivity, and the lack of technical support which limited the effectiveness of E-learning for students and instructors.

Teymori and Fardin (2020) also noted that the contextual and technological challenges limited the delivery of learning through online platforms during the COVID19 pandemic. The contextual challenges included inadequate or lack of training provided to the instructors. The others included the lack of E-learning awareness, inadequate planning, and lack of support by educational institution management. The 
technological challenges were characterized by a lack of access to computers and a strong internet network.

In another study, Mpungose (2020) established that the technical factors that limit E-learning amongst students include the low quality of software used on the platform and also the low-quality educational packages. Students are easily turned off from the E-learning platforms if they found them not user friendly and may refuse to collaborate with their instructors. Poorly designed platforms also make it increasingly difficult for instructors to follow up on their students and evaluate the learning progress that they are making over time.

\section{Research Questions \& Contributions}

Higher education institutions in the State of Kuwait lack experience in the field of distance education and digital education. In light of the disruption of school life due to the pandemic of the covid-19 virus, it became important to apply E-learning in colleges and government universities in the State of Kuwait. In order to apply E-learning in a way that ensures the quality of education and contributes to achieving educational goals set by higher education institutions, an action plan must be prepared to address the problems associated with the implementation of e-learning. It can be argued here that there are multi-level challenges and requirements of applying E-learning such as personal related challenges, intrapersonal related challenges, and external related challenges. Therefore, the current research provides the applied colleges with recommendations to help them in solving the educational and technical challenges as well as to find out most effective implications that are in line with the educational philosophy of applied colleges. These recommendations and implications are addressed to students, faculty members, decision-makers, and technical support members.

One question should be asked here is "how do undergraduates perceive E-learning in Kuwaiti applied colleges, and it is requirements in light of the confronting educational and technical challenges?" In order to find a complete answer for this chief question, sub-questions are set as the following:

- What are the attitudes of undergraduates towards E-learning in Kuwaiti Applied colleges?

- What are the most prominent educational and technical challenges resulting from learning through electronic platforms?

- What are the most prominent educational and technical requirements that must be met to achieve the quality of education in E-learning from the perspective of students?

- Are there statistically significant differences in the attitudes of the participants, and the educational and technical challenges and requirements according to the variables of the study?

\section{Methodology}

\subsection{Research Sample}

Applied colleges are distinguished from other colleges in the State of Kuwait by adopting education based on practical application and field training within their educational programs. Applied colleges include the College of Basic Education, the College of Technological Studies, the College of Business Studies, the College of Health Sciences and the College of Nursing. The population of the study consists of 38441 undergraduates affiliated in these five colleges as illustrated in Table 1.

Simple random sampling is applied by asking undergraduates from the five Applied Colleges to complete an E-survey. The total number of participants is 1650 undergraduates (376 males and 1274 females). According to the demographic information, $61 \%$ of the participants own a personal computers and almost similar percentage of the participants use Microsoft office. Meanwhile, $25 \%$ of the participants have enrolled in E-learning training courses. 


\begin{tabular}{|c|c|c|c|c|}
\hline College & Gender & $\mathbf{N}$ & Percentage & Total \\
\hline \multirow{2}{*}{ College of Basic Education } & Male & 4463 & $23 \%$ & \multirow{2}{*}{19561} \\
\hline & Female & 15098 & $77 \%$ & \\
\hline \multirow{2}{*}{ College of Technological Studies } & Male & 5600 & $85 \%$ & \multirow{2}{*}{6611} \\
\hline & Female & 1011 & $15 \%$ & \\
\hline \multirow{2}{*}{ College of Business Studies } & Male & 3315 & $37 \%$ & \multirow{2}{*}{9054} \\
\hline & Female & 5739 & $63 \%$ & \\
\hline \multirow{2}{*}{ College of Health Sciences } & Male & 723 & $36 \%$ & \multirow{2}{*}{1988} \\
\hline & Female & 1265 & $64 \%$ & \\
\hline \multirow{2}{*}{ College of Nursing } & Male & 548 & $45 \%$ & \multirow{2}{*}{1227} \\
\hline & Female & 679 & $55 \%$ & \\
\hline \multirow{2}{*}{ All five colleges } & Male & 14649 & $38 \%$ & \multirow{2}{*}{38441} \\
\hline & Female & 23792 & $62 \%$ & \\
\hline
\end{tabular}

Table 1. The research population based on gender

\begin{tabular}{|c|c|c|c|c|}
\hline Variable & Level & $\mathbf{N}$ & Percentage & Total N (\%) \\
\hline \multirow{2}{*}{ Gender } & Male & 376 & $22.8 \%$ & \multirow{2}{*}{$1650(100 \%)$} \\
\hline & Female & 1274 & $77.2 \%$ & \\
\hline \multirow{2}{*}{ Own a computer } & Yes & 970 & $58.8 \%$ & \multirow{2}{*}{$1650(100 \%)$} \\
\hline & No & 680 & $41.2 \%$ & \\
\hline \multirow{2}{*}{ Experience in Microsoft office } & Yes & 1003 & $60.8 \%$ & \multirow{2}{*}{$1650(100 \%)$} \\
\hline & No & 647 & $39.2 \%$ & \\
\hline \multirow{2}{*}{ E-learning training } & Yes & 410 & $24.8 \%$ & \multirow{2}{*}{$1650(100 \%)$} \\
\hline & No & 1240 & $75.2 \%$ & \\
\hline \multirow{5}{*}{ College } & College of Basic Education & 1038 & $62.9 \%$ & \multirow{5}{*}{$1650(100 \%)$} \\
\hline & College of Business Studies & 272 & $16.5 \%$ & \\
\hline & College of Health Sciences & 193 & $11.7 \%$ & \\
\hline & College of Technological Studies & 91 & $5.5 \%$ & \\
\hline & College of Nursing & 56 & $3.4 \%$ & \\
\hline
\end{tabular}

Table 2. The demographic information of the participants

Most of the participants are undergraduates in basic education college followed by college of Business studies, college of health sciences, college of technological studies, and college of nursing respectively.
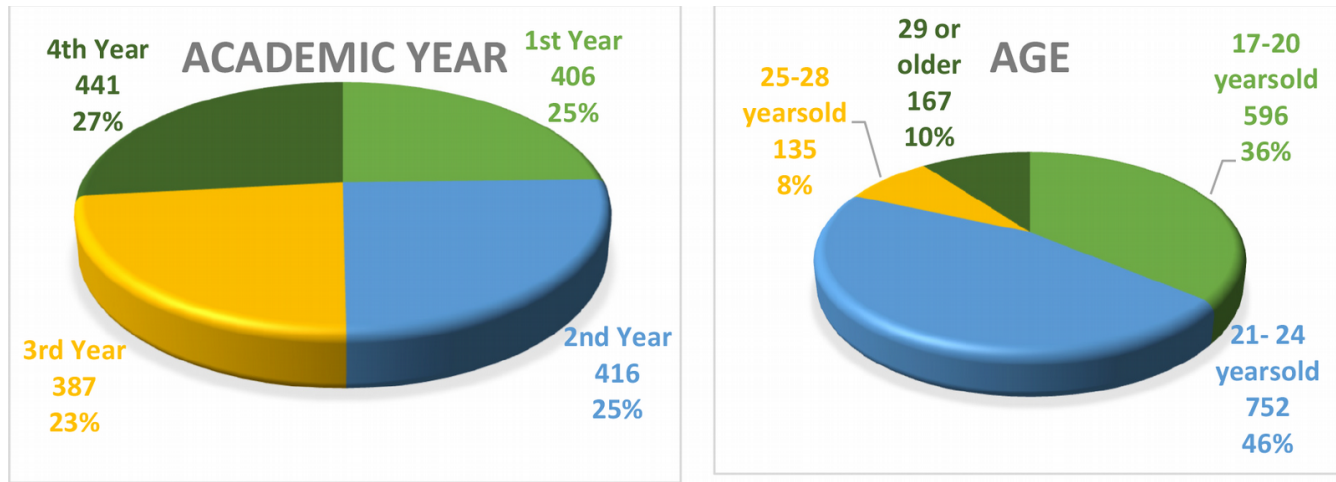

Figure 1. Participants' information according to age and academic year

As illustrated in Figure 1, the majority of participant are under 25 years old $(82 \%)$. The percentage of participants according to academic year are almost equal where the percentages ranged between $23 \%$ to $27 \%$. 
In the qualitative phase, 37 interviewees have participated in focus groups interviews through Zoom software program. The total recorded duration was 266 minutes for all interviews. Groups from each college were asked to participate in this phase as is demonstrated in the Table 3.

\begin{tabular}{|c|c|c|c|c|}
\hline $\begin{array}{c}\text { Group } \\
\text { number }\end{array}$ & College & $\begin{array}{c}\text { Number of } \\
\text { interviewees }\end{array}$ & $\begin{array}{c}\text { Duration } \\
\text { M:S }\end{array}$ & Place \\
\hline 1 & College of Technological Studies & 5 & $28: 42$ & Zoom program \\
\hline 2 & College of Nursing & 5 & $34: 20$ & Zoom program \\
\hline 3 & College of Business Studies & 5 & $14: 52$ & Zoom program \\
\hline 4 & College of Health Sciences & 5 & $22: 04$ & Zoom program \\
\hline 5 & College of Basic Education & 6 & $93: 02$ & Zoom program \\
\hline 6 & College of Basic Education & 6 & $48: 32$ & Zoom program \\
\hline 7 & College of Basic Education & 5 & $20: 22$ & Zoom program \\
\hline
\end{tabular}

Table 3. General information of focus group interviews

\subsection{Methods}

Multiple methods have been developed for the current study based in research design, namely, questionnaires, and focus groups. There are many advantages of conducting multiple data collection methods such as investigating the area of study from different angles and compensating the weakness of individual research method.

\subsubsection{Online Questionnaire}

\begin{tabular}{|c|c|c|c|}
\hline Scale & Domain & $\mathbf{N}$ of items & Exemplary item \\
\hline \multirow{4}{*}{$\begin{array}{l}\text { Attitude } \\
\text { towards } \\
\text { E-learning }\end{array}$} & Educational goals & 4 & $\begin{array}{l}\text { Educational goals can be easily achieved through e- } \\
\text { learning }\end{array}$ \\
\hline & Student's competencies & 5 & E-learning improves the student's self-learning skills. \\
\hline & Interactive learning & 4 & $\begin{array}{l}\text { E-learning provides an opportunity for positive } \\
\text { interaction between undergraduates with one another. }\end{array}$ \\
\hline & Alternative education & 5 & $\begin{array}{l}\text { E-learning programs offer alternative services to } \\
\text { traditional academic services }\end{array}$ \\
\hline \multirow{3}{*}{$\begin{array}{l}\text { Educational } \\
\text { challenges \& } \\
\text { requirements }\end{array}$} & Social participation & 6 & $\begin{array}{l}\text { E-learning limits students' interactions with the course } \\
\text { professor and with their colleagues }\end{array}$ \\
\hline & Pedagogical practices & 7 & $\begin{array}{l}\text { It is difficult for the professor to diversify the student- } \\
\text { centered activities and teaching methods when applying e- } \\
\text { learning. }\end{array}$ \\
\hline & Self-study ability & 7 & $\begin{array}{l}\text { Undergraduates are not proficient in using the E-learning } \\
\text { resources provided by the college as electronic journals. }\end{array}$ \\
\hline \multirow{4}{*}{$\begin{array}{l}\text { Technical } \\
\text { challenges \& } \\
\text { requirements }\end{array}$} & Training courses & 4 & $\begin{array}{l}\text { The student needs LMS training courses such as Moodle } \\
\text { platform. }\end{array}$ \\
\hline & Synchronous learning & 4 & $\begin{array}{l}\text { College-approved E-learning programs face technical } \\
\text { problems due to the increase in the number of users } \\
\text { during peak times. }\end{array}$ \\
\hline & LMS & 4 & $\begin{array}{l}\text { The course professor does not have sufficient background } \\
\text { about the characteristics and options offered by distance } \\
\text { education programs. }\end{array}$ \\
\hline & IT support & 6 & $\begin{array}{l}\text { E-learning requires a dedicated technical support unit for } \\
\text { distance education programs that maintains and develops } \\
\text { them periodically. }\end{array}$ \\
\hline
\end{tabular}

Table 4. Exemplary items from questionnaire's sections 
An online questionnaire has been developed by the researchers to elicit faculty members' and students' attitudes towards E-learning, the educational and technical challenges confronting them in E-learning, the educational and technical requirements needed for providing a good quality of E-learning. The questionnaire has two versions one for the faculty members and the other for the students, however both versions has similar items with narrow modifications except the section of demographic information. The questionnaire comprises, sequentially, a number of demographic questions, 18 close-ended items in the second section focus on attitudes towards E-learning, 20 close-ended items in the third section assigned for the educational challenges of and requirements for E-learning, and 18 close-ended items in the last section assigned for the technical challenges of and requirements for E-learning. The participants were asked to rate their perceptions using a 5-point Likert scale ranging from "strongly agree" to "strongly disagree". Some examples of closed-end items for each section can be shown in Table 4.

\subsubsection{Online Focus Groups}

The second method is online focus group through zoom software program. It could be argued that face to face interviewing enables interviewer to contact with interviewee based on verbal and non-verbal communication comparing with the online interviewing forms (chatroom and e-mail forms). Nevertheless, face to face interviewing could limit sample from the most "relevant to accessible people" to due to many reasons such as "interviewees spread across the country", or due to the curfew caused by the pandemic of Covid-19, as is the case today (Flick, 2009: page 266). Also, the synchronized communication via the Internet has become more advanced, as the interviewer can communicate with participants via a live broadcast (audio and video), which allow interviewer to communicate verbally and non-verbally with participants.

With respect to the interviewing schedule, it consists of 17 open-ended questions divided into four sections, beginning with two ice breaking questions focus on interviewee background and personal information. Then, five questions focus on attitude towards E-learning and its quality, four questions focus on educational challenges of and requirements of E-learning. The last six questions focus on technical challenges of and requirements of E-learning. Furthermore, semi-structured schedule enables the interviewer to ask questions that not prepared in advance, which means the schedule is not limited by the pre-listed questions. Last but not least, some examples of pre-prepared questions can be presented as follows:

Q3: What do you think of digital or E-learning?

Q5: How do you evaluate the quality of education provided via digital platforms? To what degree do you find it similar or different to learning inside the classroom?

Q9: How can a teacher maintain cognitive presence of undergraduates such as attention and consideration during online lectures?

Q10: How can undergraduates maintain interaction with each other and with the course professor during the implementation of E-learning in the form of simultaneous presentation or by downloading content via Moodle?

Q13: What are the skills that undergraduates and professors must be trained in before starting E-learning application?

\subsection{Pilot Study}

The questionnaire and interview schedule have been developed after following practical procedures to insure its validity and reliability. First, the researchers have reviewed relevant literature and empirical papers to compare their research methods with the current ones. Second, the inventories are examined by 3 experts form the College of Basic Education to check its appropriateness in term of content, language, style, and typos; changes were made based on their feedback. Third, pilot study is conducted to test consistencies among items, domains, and scales. The instrument was piloted with 60 undergraduates. They also were able to add notes on each item that they believed was not precise. Concerning internal reliability, the results of Cronbach's alpha presented in Table 5 ranged from .502 to .907. 


\begin{tabular}{|l|l|c|c|r|}
\hline \multicolumn{1}{|c|}{ Sub-scales } & \multicolumn{1}{|c|}{ Domain } & N of items & Items & Alpha \\
\hline \multirow{2}{*}{$\begin{array}{l}\text { Attitude } \\
\text { towards }\end{array}$} & Educational goals & 4 & EG4, EG9, EG17, EG18* & .838 \\
\cline { 2 - 5 } & Student's competencies & 5 & SC1, SC2, SC3, SC5, SC11* & .826 \\
\cline { 2 - 5 } & Interactive learning & 4 & IL10, IL12, IL13*, IL14* & .502 \\
\cline { 2 - 5 } & Alternative education & 5 & AE6, AE7, AE8, AE15*, AE16* & .778 \\
\hline \multirow{2}{*}{$\begin{array}{l}\text { Educational } \\
\text { challenges \& } \\
\text { requirements }\end{array}$} & Social participation & 6 & SP27, SP30, SP31, SP34, SP36, SP37 & .885 \\
\cline { 2 - 6 } & Pedagogical practices & 7 & PP19, PP23, PP24, PP25, PP29, PP35, PP38 & .765 \\
\cline { 2 - 6 } & Self-study ability & 7 & SA20, SA21, SA22, SA26, SA28, SA32, SA33 & .888 \\
\hline \multirow{2}{*}{$\begin{array}{l}\text { Technical } \\
\text { challenges \& } \\
\text { requirements }\end{array}$} & Training courses & 4 & TC39, TC40, TC41, TC42 & .899 \\
\cline { 2 - 6 } & Synchronous learning & 4 & SL49, SL50, SL51, SL52 & .852 \\
\cline { 2 - 6 } & LMS & 4 & LMS45, LMS46, LMS47, LMS48 & .855 \\
\cline { 2 - 6 } & IT support & 6 & IT43, IT53, IT54, IT55, IT56, IT57 & .907 \\
\hline
\end{tabular}

Table 5. Internal reliability

All the domains exceeded 7 in Cronbach's alpha test apart from interactive learning domain that reached . 502. The interactive learning domain is still acceptable, as Cronbach's alpha can be affected by the number of items. Scales that include fewer than 10 items tend to have a low Cronbach's alpha (Pallant, 2013).

\begin{tabular}{|c|c|c|c|c|c|c|c|}
\hline \multicolumn{8}{|c|}{ Attitude towards E-learning } \\
\hline \multicolumn{2}{|c|}{ Educational goals } & \multicolumn{2}{|c|}{ Student's competencies } & \multicolumn{2}{|c|}{ Interactive learning } & \multicolumn{2}{|c|}{ Alternative education } \\
\hline Item & Alpha & Item & Alpha & Item & Alpha & Item & Alpha \\
\hline EG4 & $.873^{* *}$ & SC1 & $.895^{* *}$ & IL10 & $.621 * *$ & AE6 & $.732^{* *}$ \\
\hline EG9 & $.886^{* *}$ & SC2 & $.908^{* *}$ & IL12 & $.651^{* *}$ & AE7 & $.658^{* *}$ \\
\hline EG17 & $.879 * *$ & SC3 & $.928^{* *}$ & IL13* & $.509 * *$ & AE8 & $.797 * *$ \\
\hline EG18* & $.624 * *$ & SC5 & $.823 * *$ & IL14* & $.749 * *$ & AE15* & $.713^{* *}$ \\
\hline- & - & SC11* & $.265^{*}$ & - & - & AE16* & $.742^{* *}$ \\
\hline \multicolumn{8}{|c|}{ Educational challenges $\&$ requirements } \\
\hline \multicolumn{3}{|c|}{ Social participation } & \multicolumn{2}{|c|}{ Pedagogical practices } & \multicolumn{3}{|c|}{ Self-study ability } \\
\hline Item & Alpha & & Item & Alpha & & Item & Alpha \\
\hline SP27 & $.892 * *$ & & PP19 & .181 & & SA20 & $.778^{* *}$ \\
\hline SP30 & $.701 * *$ & & PP23 & $.662^{* *}$ & & SA21 & $.831 * *$ \\
\hline SP31 & $.858^{* *}$ & & PP24 & $.824 * *$ & & SA22 & $.807 * *$ \\
\hline SP34 & $.832 * *$ & & PP25 & $.784 * *$ & & SA26 & $.891 * *$ \\
\hline SP36 & $.763^{* *}$ & & PP29 & $.696^{* *}$ & & SA28 & $.815^{* *}$ \\
\hline SP37 & $.744 * *$ & & PP35 & $.593 * *$ & & SA32 & $.675^{* *}$ \\
\hline-- & -- & & PP38 & $.789 * *$ & & SA33 & $.616^{* *}$ \\
\hline \multicolumn{8}{|c|}{ Technical challenges $\&$ requirements } \\
\hline \multicolumn{2}{|c|}{ Training courses } & \multicolumn{2}{|c|}{ Synchronous learning } & \multicolumn{2}{|c|}{ LMS } & \multicolumn{2}{|c|}{ IT support } \\
\hline Item & Alpha & Item & Alpha & Item & Alpha & Item & Alpha \\
\hline TC39 & $.866^{* *}$ & SL49 & $.721 * *$ & LMS45 & $.921 * *$ & IT43 & $.703^{* *}$ \\
\hline TC40 & $.846^{* *}$ & SL50 & $.888^{* *}$ & LMS46 & $.822^{* *}$ & IT53 & $.838^{* *}$ \\
\hline TC41 & $.906^{* *}$ & SL51 & $.854 * *$ & LMS47 & $.821 * *$ & IT54 & $.832^{* *}$ \\
\hline TC42 & $.890 * *$ & SL52 & $.865^{* *}$ & LMS48 & $.775^{* *}$ & IT55 & $.847 * *$ \\
\hline- & - & - & - & - & - & IT56 & $.911 * *$ \\
\hline- & - & - & - & - & - & IT57 & $.866^{* *}$ \\
\hline
\end{tabular}

** Correlation is significant at the 0.01 level (2-tailed).

* Correlation is significant at the 0.05 level (2-tailed).

Table 6. Internal validity 
According to Table 6, almost all 57 items were significantly correlated with their domains, where the correlations ranged between .593 to .921 , except item 19 that was weakly correlated with it is domain. Moreover, the correlations between domains and their scales were also significantly correlated in which the results ranged between .750 to .925 as it illustrated in Table 7 .

\begin{tabular}{|c|c|c|c|c|}
\hline Scales & \multicolumn{4}{|c|}{ Domains } \\
\hline \multirow{2}{*}{ Total of perspective } & Educational goals & Student's competencies & Interactive learning & Alternative education \\
\hline & $.917 * *$ & $.925^{* *}$ & $.750^{* *}$ & $.923 * *$ \\
\hline \multirow{2}{*}{$\begin{array}{l}\text { Total of Educational } \\
\text { challenges \& } \\
\text { requirements }\end{array}$} & Social participation & Pedagogical practices & Self-study ability & \\
\hline & $.916^{* *}$ & $.923 * *$ & $.965^{* *}$ & \\
\hline \multirow{2}{*}{$\begin{array}{l}\text { Total of Technical } \\
\text { challenges \& } \\
\text { requirements }\end{array}$} & Training courses & Synchronous learning & LMS & IT support \\
\hline & $.882^{* *}$ & $.830 * *$ & $.924 * *$ & $.908^{* *}$ \\
\hline
\end{tabular}

** Correlation is significant at the 0.01 level (2-tailed).

Table 7. Correlations between domains and scales

\subsection{Data Analysis}

The raw data fed into SPSS software program (Statistical Package for Social Sciences), version 23.0. descriptive statistical analysis such as percentages, frequencies, means, and standard deviations were performed to present the demographic information of participant and figure out the means of scales and subscales. Also, the current study applied inferential statistical analysis such as variance analysis and correlation analysis in order to identify possible statistical comparison and relationships among the overall responses.

On the other hand, the digital data derived from students' focus groups were transferred to transcripts and then fed into MAXQDA 2020 (Max Qualitative Data Analysis). The qualitative raw data were analyzed by adopting the model of "categorizing indexing" based on Radnor's analysis strategy (Radnor, 2002). This model provides six stages, starting with "topic ordering" Major themes can be ordered after scanning and reading the transcripts many times, especially when the interviews' and focus groups' schedules focus on specific scopes. The second stage is "constructing categories" under each major theme in order to move to the third stage which is "reading for content". Th third stage aims to identify and highlights statements from the transcripts by carefully reading the whole text data. The fourth stage is "completing the coding sheets", where codes are grouped in the related categories. the next stage is "generating coded transcripts" which stands on transferring coded extracts from the raw transcripts to the coded transcripts. "analysis to interpretation" is the final stage, in which specific description is given to each category to review and select exemplary extracts for presenting the finding.

\section{Findings}

The findings of this study point to the attitude of undergraduates towards E-learning, educational challenges and requirements, and technical challenges and requirements in Kuwaiti Applied Colleges. Hence, the findings are presented into two sections quantitative findings and qualitative findings.

\subsection{Quantitative Findings}

Undergraduates' attitudes are revealed. According to Table 8, participants have neutral attitudes towards E-learning $(M=3.14, S D=1)$ in which the means of domains ranged between 3 to 3.29.

Meanwhile, it appears that the educational challenges and requirements scored 3.43 indicating that undergraduates see these challenges as high obstacles that could hinder their learning process. The highest educational challenge was self-study ability $(M=3.48, S D=1.01)$ then social participation and pedagogical practices. Nevertheless, undergraduates are afraid from technical challenges $(M=3.92, S D=.96)$ more than educational ones. Their first concern is the weakness of technical support services $(M=4.17, S D=1.01)$, 
followed by the difficulty of using LMS programs $(M=3.93, S D=1.1)$. Then, the lack of training courses related to distance education and problems related to simultaneous education.

An independent-samples t-test revealed significant differences between the scores of undergraduates received training courses in LMS and untrained undergraduates (Table 9) in all domains apart of IT support domain that appeared to be the supreme requirement by all participants.

\begin{tabular}{|c|c|c|c|c|c|c|}
\hline Sub-scale & Domain & $\mathbf{N}$ & $\mathbf{M}$ & SD & Descent order & Level \\
\hline \multirow{5}{*}{$\begin{array}{l}\text { Attitude towards } \\
\text { E-learning }\end{array}$} & Educational goals & \multirow{5}{*}{1650} & 3.29 & 1.13 & 1 & Neutral \\
\hline & Student's competencies & & 3.15 & 1.16 & 2 & Neutral \\
\hline & Alternative education & & 3.12 & 1.13 & 3 & Neutral \\
\hline & Interactive learning & & 3.00 & .91 & 4 & Neutral \\
\hline & Total & & 3.14 & 1.00 & - & Neutral \\
\hline \multirow{4}{*}{$\begin{array}{l}\text { Educational } \\
\text { challenges \& } \\
\text { requirements }\end{array}$} & self-study ability & \multirow{4}{*}{1650} & 3.48 & 1.11 & 1 & high \\
\hline & Social participation & & 3.42 & 1.25 & 2 & high \\
\hline & pedagogical practices & & 3.40 & .92 & 3 & high \\
\hline & Total & & 3.43 & 1.02 & - & high \\
\hline \multirow{5}{*}{$\begin{array}{l}\text { Technical } \\
\text { challenges \& } \\
\text { requirements }\end{array}$} & IT support & \multirow{5}{*}{1650} & 4.17 & 1.01 & 1 & high \\
\hline & LMS & & 3.93 & 1.10 & 2 & high \\
\hline & Training courses & & 3.78 & 1.17 & 3 & high \\
\hline & Synchronous learning & & 3.64 & 1.17 & 4 & Neutral \\
\hline & Total & & 3.92 & .96 & - & High \\
\hline
\end{tabular}

Table 8. Means and stranded deviations of sub-scales and domains

\begin{tabular}{|c|c|c|c|c|c|c|c|c|c|}
\hline Sub-scale & Domain & $\begin{array}{c}\text { E-learning } \\
\text { training course }\end{array}$ & $\mathbf{N}$ & $\mathbf{M}$ & SD & $\begin{array}{l}\text { Equality of } \\
\text { variances }\end{array}$ & df & $\mathbf{T}$ & Sig \\
\hline \multirow{8}{*}{$\begin{array}{l}\text { Attitude towards } \\
\text { E-learning }\end{array}$} & \multirow{2}{*}{ Educational goals } & Yes & 410 & 3.73 & 1.02 & \multirow{2}{*}{ Not assumed } & \multirow{2}{*}{760} & \multirow{2}{*}{9.805} & \multirow{2}{*}{$.000^{*}$} \\
\hline & & $\mathrm{No}$ & 1240 & 3.15 & 1.12 & & & & \\
\hline & \multirow{2}{*}{$\begin{array}{l}\text { Student's } \\
\text { competencies }\end{array}$} & Yes & 410 & 3.61 & 1.04 & \multirow{2}{*}{ Not assumed } & \multirow{2}{*}{768} & \multirow{2}{*}{9.969} & \multirow{2}{*}{$.000^{*}$} \\
\hline & & No & 1240 & 3.00 & 1.15 & & & & \\
\hline & \multirow{2}{*}{$\begin{array}{l}\text { Alternative } \\
\text { education }\end{array}$} & Yes & 410 & 3.59 & 1.04 & \multirow{2}{*}{ Assumed } & \multirow{2}{*}{1648} & 10.08 & \multirow{2}{*}{$.000^{*}$} \\
\hline & & $\mathrm{No}$ & 1240 & 2.96 & 1.11 & & & 1 & \\
\hline & \multirow{2}{*}{$\begin{array}{l}\text { Interactive } \\
\text { learning }\end{array}$} & Yes & 410 & 3.32 & 1.04 & \multirow{2}{*}{ Assumed } & \multirow{2}{*}{1648} & \multirow{2}{*}{8.265} & \multirow{2}{*}{$.000^{*}$} \\
\hline & & No & 1240 & 2.90 & 1.11 & & & & \\
\hline \multirow{6}{*}{$\begin{array}{l}\text { Educational } \\
\text { challenges \& } \\
\text { requirements }\end{array}$} & \multirow{2}{*}{ Self-study ability } & Yes & 410 & 3.15 & 1.13 & \multirow{2}{*}{ Assumed } & \multirow{2}{*}{1648} & \multirow{2}{*}{-7.122} & \multirow{2}{*}{$.000^{*}$} \\
\hline & & No & 1240 & 3.59 & 1.08 & & & & \\
\hline & \multirow{2}{*}{$\begin{array}{l}\text { Social } \\
\text { participation }\end{array}$} & Yes & 410 & 3.03 & 1.24 & \multirow{2}{*}{ Assumed } & \multirow{2}{*}{1648} & \multirow{2}{*}{-7.451} & \multirow{2}{*}{$.000^{*}$} \\
\hline & & No & 1240 & 3.55 & 1.23 & & & & \\
\hline & \multirow{2}{*}{$\begin{array}{l}\text { Pedagogical } \\
\text { practices }\end{array}$} & Yes & 410 & 3.25 & .98 & \multirow{2}{*}{ Not assumed } & 651 & 2617 & $000 *$ \\
\hline & & No & 1240 & 3.45 & .89 & & 051 & -3.041 & .000 \\
\hline & $I^{n}$ & Yes & 410 & 4.09 & 1.01 & 1 & 1640 & & 07 \\
\hline & 11 support & No & 1240 & 4.19 & 1.01 & Assumed & 1048 & -1.110 & .81 \\
\hline & IMS & Yes & 410 & 3.72 & 1.09 & Accumed & $1648+290$ & 16 & 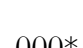 \\
\hline Technical & LMIS & No & 1240 & 3.99 & 1.09 & Assumed & 1048 & -4.440 & $.000^{\star}$ \\
\hline requirements & Training courses & Yes & 410 & 3.46 & 1.23 & Not ascumed & 652 & -6240 & $000 *$ \\
\hline & 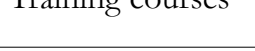 & No & 1240 & 3.90 & 1.13 & Not assumed & 052 & -0.240 & .000 \\
\hline & Synchronous & Yes & 410 & 3.89 & 1.17 & Assumed & 1648 & -5151 & $000 *$ \\
\hline & learning & No & 1240 & 3.73 & 1.15 & & 1048 & & $.000^{m}$ \\
\hline
\end{tabular}

Table 9. Comparing groups of trained undergraduates and untrained undergraduates 
Trained $(N=410)$ and untrained undergraduates $(N=1240)$ differed significantly in all domains of attitudes towards E-learning, in which trained undergraduates hold more positive than untrained ones. Educational challenges such as self-study, social participation, pedagogical practices challenges can be handled by trained undergraduates other than untrained undergraduates who find them Obstacles to their education process. the result of social participation is an example of these differences, $t(1648)=-7.45$, $p=.000$, with untrained students $(M=3.55, S D=1.23)$ scoring higher compared to trained ones $(M=3.03$, $S D=1.24)$. similarly, untrained undergraduates scored higher means than the means of trained students in almost all technical challenges.

Another independent-samples t-test revealed significant differences between the scores of experienced undergraduates in using Microsoft office $(N=1003)$ and unexperienced ones $(N=647)$. According to Table 10, experienced undergraduates hold positive attitudes unlike the unexperienced students who hold negative feelings towards E-learning. For example, the domain of educational goal, $t(1340)=18.1, p=.000$, with experienced students $(M=3.66, S D=1.01)$ scoring higher compared to unexperienced ones $(M=2.72$, $S D=1.05)$.

The Table 10 also indicates that experienced students are less afraid of educational and technical challenges than other students. But both of them stress the importance of technical support as a key requirement for the success of the distance learning process.

\begin{tabular}{|c|c|c|c|c|c|c|c|c|c|}
\hline Sub-Scale & Domain & $\begin{array}{l}\text { Experience in } \\
\text { Microsoft office }\end{array}$ & $\mathbf{N}$ & $\mathbf{M}$ & SD & $\begin{array}{c}\text { Equality of } \\
\text { variances }\end{array}$ & df & $\mathbf{T}$ & Sig \\
\hline \multirow{8}{*}{$\begin{array}{l}\text { Attitude } \\
\text { towards } \\
\text { E-learning }\end{array}$} & \multirow{2}{*}{ Educational goals } & Yes & 1003 & 3.66 & 1.01 & \multirow{2}{*}{ Not assumed } & \multirow{2}{*}{1340} & \multirow{2}{*}{18.098} & \multirow{2}{*}{$.000^{*}$} \\
\hline & & No & 647 & 2.72 & 1.05 & & & & \\
\hline & \multirow{2}{*}{$\begin{array}{l}\text { Student's } \\
\text { competencies }\end{array}$} & Yes & 1003 & 3.55 & 1.03 & \multirow{2}{*}{ Not assumed } & \multirow{2}{*}{1332} & \multirow{2}{*}{18.900} & \multirow{2}{*}{$.000^{*}$} \\
\hline & & No & 647 & 2.54 & 1.07 & & & & \\
\hline & \multirow{2}{*}{$\begin{array}{l}\text { Alternative } \\
\text { education }\end{array}$} & Yes & 1003 & 3.49 & 1.03 & \multirow{2}{*}{ Assumed } & \multirow{2}{*}{1648} & \multirow{2}{*}{18.483} & \multirow{2}{*}{$.000^{*}$} \\
\hline & & No & 647 & 2.54 & 1.01 & & & & \\
\hline & \multirow{2}{*}{$\begin{array}{l}\text { Interactive } \\
\text { learning }\end{array}$} & Yes & 1003 & 3.22 & .89 & \multirow{2}{*}{ Assumed } & \multirow{2}{*}{1648} & \multirow{2}{*}{13.131} & \multirow{2}{*}{$.000^{*}$} \\
\hline & & No & 647 & 2.65 & .84 & & & & \\
\hline \multirow{6}{*}{$\begin{array}{l}\text { Educational } \\
\text { challenges \& } \\
\text { requirements }\end{array}$} & \multirow{2}{*}{ Self-study ability } & Yes & 1003 & 3.27 & 1.05 & \multirow{2}{*}{ Assumed } & \multirow{2}{*}{1648} & \multirow{2}{*}{-9.638} & \multirow{2}{*}{$.000^{*}$} \\
\hline & & No & 647 & 3.80 & 1.12 & & & & \\
\hline & \multirow{2}{*}{$\begin{array}{l}\text { Social } \\
\text { participation }\end{array}$} & Yes & 1003 & 3.17 & 1.20 & \multirow{2}{*}{ Assumed } & \multirow{2}{*}{1648} & \multirow{2}{*}{$10 . \overline{183}$} & \multirow{2}{*}{$.000^{*}$} \\
\hline & & No & 647 & 3.80 & 1.23 & & & & \\
\hline & \multirow{2}{*}{$\begin{array}{l}\text { Pedagogical } \\
\text { practices }\end{array}$} & Yes & 1003 & 3.33 & .86 & Not assumed & 1245 & -3.707 & $.000^{*}$ \\
\hline & & No & 647 & 3.51 & .99 & 1vol assumed & & & .000 \\
\hline & & Yes & 1003 & 4.23 & .90 & & & & \\
\hline & IT support & No & 647 & 4.07 & 1.16 & Not assumed & 1130 & 2.896 & $.004^{*}$ \\
\hline & & Yes & 1003 & 3.86 & 1.03 & & & & \\
\hline Technical & LMS & No & 647 & 4.03 & 1.19 & Not & 123 & -3.125 & $.002^{*}$ \\
\hline $\begin{array}{l}\text { challenges \& } \\
\text { requirements }\end{array}$ & Trainino courses & Yes & 1003 & 3.66 & 1.12 & A ccumed & 1648 & -5.308 & $000 *$ \\
\hline & iraming courses & No & 647 & 3.97 & 1.20 & Assumed & 1040 & -5.500 & .000 \\
\hline & Synchronous & Yes & 1003 & 3.52 & 1.13 & & 18 & & $000 *$ \\
\hline & learning & No & 647 & 3.83 & 1.20 & Assumed & 1048 & $-5 . \angle 20$ & $.000^{4}$ \\
\hline
\end{tabular}

Table 10. Comparing groups of experienced undergraduates and unexperienced undergraduates

\subsection{Qualitative Findings}

Focus group interviews were conducted with students from PAAET Colleges. Qualitative analysis was used to explore the students' perspectives of e-learning, educational challenges and requirements and technical challenges and requirements. 


\subsubsection{Perspective of E-learning}

This theme presents the students' attitudes and perspectives toward the E-Learning. This is reflected in the following sub-themes: E-learning during COVID-19 pandemic, the availability of E-Learning, instructional support, and alternative education.

E-learning during COVID-19 pandemic. Regarding the implementation of E-learning in PEAAT Colleges during the COVID-19 pandemic. Many students agreed that the education at the PEAAT Colleges should be resumed through implementing E-Learning, especially for the theoretical courses. A student at the College of Basic Education mentioned " closing the campus and postponing [the semester] during the COVID-19 pandemic is not helpful, the students will not be able to graduate this year, therefore the students should continue their education and the E-learning is the solution and savior in this situation".

The availability of E-learning. As students discussed their perspective of E-Learning, they mentioned the advantages of using E-learning at PAAET Colleges. Students at College of Basic Education said "the online lecture will be available to me at any time when I need it. [if] I forgot a certain point that the doctor said ... I will be able to return it at any time and hear what he said or what the point is and repeat it more than once in order to understand it" another student mentioned that "I see [E-Learning] more enjoyable than the traditional education".

Instructional support. However, the students also expressed the challenges of applying the E-learning in PAAET Colleges as a student from College of Health Science said "... there will be a lack of communication skill, meaning when I am sitting at home, there will be no interaction with people, students, and doctors, and whatever knowledge I have without the communication skills I will not be able to communicate with others". Another student at the same College said "I mean, for example, we are at the College of health sciences, we have the lab. We must work with our hands, see with our eyes, behave as if we are working in the hospital, this thing is difficult to do in E-platforms, E-learning could work with the theoretical courses not practical courses". A student from College of Nursing stated that "difficulty of practical courses, we do more work than we receive information from the tutors... besides all materials are in the laboratory. ... if I've e-learned and then graduated, what's going to happen if I got a job?"

Alternative education. Moreover, the students reported that the E-learning is not alternative for the traditional education. As a student from College of Health Science reported that: "E-learning will not be an alternative to the traditional education because the College of Health Science deals with panels, for example in laboratories and emergencies. These skills need to be learned closely. After all, there is no replacement". On the other hand, some students suggested that E-learning could be applied along with the traditional education (blended education), a student from College of Basic Education stated that “... but why not to support online learning by seeing it as an assistant method that complements the traditional education ... if the professor forgot to mention anything in the class, ... E-Learning will be an assistant factor, I mean, but of course the traditional education is the basis, while [E-Learning] is complementary".

\subsubsection{Educational Challenges \& Requirements}

As students discussed their challenges regarding the implementation of E-Learning, the issues of the class size, students' attention and duration of the online class, pedagogical practices, and self-study ability were introduced by nearly every focus group. Therefore, the students discussed ways to overcome these challenges.

Attention span and length of online class. Regarding to the duration of the online class, a student from College of Basic Education recommended that "if the time of the online class is too long, then it should be a break for every 30 minutes". A student from College of Business Studies had the same opinion regarding the duration of the class as she motioned that "half an hour is fine, [but] more than half an hour... the majority of students would go to sleep and play with their phone ... it is half an hour in which the lesson will be explained for the students to understand everything" Another student suggested that "the 
professor should summarize the lecture and talk about the essential things and then assign homework to the students".

Interactivity and class size. The students at the College of Business Studies suggested that the "class size should be between 20 to 30 students" to maintain interactive class. A student from College of Basic Education thought that "The fewer number of students in the online class, the more interactive and more successful for the students". Another student from the same College viewed that the greater number of students would be challenging for the professor to control over the online class and "it would lead to directional teaching".

Pedagogical practices. Consistently, the students determined the pedagogical practices such as applying a discussion as a practice to be used with the students at the online classes. A student from College of Basic Education said " ...every ten minutes the professor should give the students two to three questions to create more interaction between the professor and the students as well between the students in the online class". A student from College of Nursing stated that "Exactly. It is not just delivering and explaining, and we hearing the lecture, you know? It must be a discussion or group work that's the thing that helps the student to focus in the online class".

Self-study ability. Self-study ability was considered as an educational requirement for the students to obtain in order to successfully implement E-Learning. In this excerpt, a student from College of Basic Education stressed that "The student must prepare himself in sufficient time before the class start, for example, he has a paper and a pen so he takes note.. most of these things that I see, I mean, it helps the students to focus". While, a student from College of Nursing stated that "... I mean, if you prepare the atmosphere and surround the things that would help you to study and manage your time".

Progress evaluation. In addition, the students gave some suggestion to effectively evaluate the students' progress (exams). A student from College of Basic Education believed that "cheating is a big problem in online learning ... perhaps the best way is to use cam option to mentor students' behavior during the test. [also] I think this method is the most appropriate method for essay evaluate the student's ability and understanding of the whole material". Another student said" but in terms of life cam, I strongly advise you to use the cam, even if you do not have a computer, you can download in your phone". Another student stated that "some students can easily cheat in online test because the college do not use lock down browser programs".

\subsubsection{Technical Challenges \& Requirements}

Two subthemes emerged from the technical requirements: interface, internet connections. Whereas, the most relevant focus group discourses on the theme of technical requirements were as follow: training course, trail period, and IT support.

Trail period. The students also, mentioned the importance of having a trail period before implement the Elearning in PEAAT Colleges. A student from the College of Basic Education stated that "I mean, a course (trail period), even if one week before studying, to practice how do we upload files? How do we make sure that the homework is uploaded? How to do exams... I see if we focus on the basic matters that serve the student to complete distance education process". A student at the College of Nursing suggested that "I mean, OK, a week and a half, maximum two weeks to be familiar with [E-Learning] platform, I mean ... they inform us about it because our college did not apply distance education before".

Training course. The students highlighted the technical requirements to effectively implement E-learning in PAAET Colleges. Technical training course, the students' statements reflected the importance of having training courses for the faculty as well as for the students. A student at the College of Basic Education said "The educational courses are useful. Gives the opportunity to practice... I have to apply and see what is correct to do. it's then the training courses are helpful". Another student reported that "at least if it was in a training course to teach me the things that I will face, we will reach an excellent level that prepares us 
to resume the course, I cannot say without any problems, but I mean, we will resume the course very well".

User interface. Some of the students, like students at College of Basic Education appeared to be concerned about the user interface for the LMS (Moodle). A student at the College of Basic Education reported that "the structure of the user interface for the Moodle system is very difficult". Another student said "very very difficult. I mean, even when I want to see my grades, I cannot... I should try a thousand way to enter the system, what I do!”.

Internet Connection. Another technical challenge that the students raised was the internet connection. Most of the students reported the lack of the internet connection either in their houses or at the PEAAT Colleges. A student at the College of Basic Education said "I mean, if they tell me to classify the problems in order, what is the most important problem I will face? ... poor Internet and server problems".

IT support. Consistently, the students mentioned that implementing E-learning in PEAAT Colleges requires sufficient support from IT to assist the students when implementing E-Learning. A student from the College of Health Science stated that "there must be a technical support or specialized people to help with problems. His job is to help students if they encounter a problem. Problems are present in traditional education distance education as well". A student from College of Basic Education reported that "There must be people who is specialized in helping students. I mean, the student does not ask for help from his colleagues. It should be a special unit, if the student faced a problem with, he must talk to them IT support".

\section{Discussion}

Quantitative and qualitative findings are discussed here based on relevant literature and previous studies. Three major areas are highlighted to draw a holistic picture of undergraduates' attitudes, challenges, and requirements for E-learning.

\subsection{Students' Attitudes towards E-learning}

In spite of students addressed several challenges and difficulties related to E-learning, they held neutral sentiments, their attitudes towards E-learning were unbiased $(M=3.14)$. Also, students who have knowledge of using Microsoft Office programs are more optimistic than students who do not use Office programs. This finding appeared to be different from previous findings by Adnan and Anwar (2020) and by Alkharang and Ghinea (2013), who concluded that students were biased against the E-learning. The possible reason of not being biased against E-learning that students were aware of the advantages and disadvantages of E-learning. Indeed, students were reluctant to postpone their studies due to the outbreak of the COVIS-19 pandemic, so that they found E-learning is great chance to avoid any delay on their graduation plans. They also pointed that E-learning platforms allows them to access the online lessons anytime and attend lectures from distance. On the other side, students admitted the difference between learning on-campus and E-learning, differences such as lack of communications (Ali \& Magalhaes. 2012), lack of pedagogical practices, and lack of instructional support (Alkharang, 2014; Al-Azawei, Parslow \& Lundqvist, 2016). Therefore, students do not see online learning is an alternative of on-campus learning, yet it is a temporary solution to cope with the outbreak of the COVID-19 pandemic.

\subsection{Educational Challenges and Requirements}

As stated, students are aware of several challenges including the educational ones which identified as high challenges such as poor self-study skills, limited pedagogical activities, lack of participation and interactivity, students' attentions and length of online class, and class size.

Diversification of teaching methods and the use of different pedagogical applications is one of the students' demands. Students do not want to follow a single style of teaching that is often based on indoctrination. Therefore, they demand the provision of educational support by teachers to properly deliver the scientific content (Koçoğlu \& Tekdal, 2020). In addition to the necessity to find practical 
solutions that regulate the process of evaluating student performance and prevent unethical behaviors such as cheating in tests and scientific plagiarism. Where students see that the lack of appropriate technical and administrative tools will lead to a defect in the students 'evaluation (Al-Hunaiyyan, Alhajri \& Al-Sharha , 2018; Suryaman et al., 2020).

The results also indicate that self-learning skills are one of the most important requirements of e-learning, as the student must possess these skills in order to be able to manage his/her learning process remotely and to use it with different learning resources (Arinto, 2016; Al-Azawei et al., 2016). Therefore, a student who is unable to organize his distance learning process will face difficulties during the application of online learning. The matter does not stop at self-learning skills but extends to external factors that pose challenges as indicated by the participants such as maintaining students' attention and stimulating their participation and interaction throughout the virtual lecture. Students are wary of the problems they will face due to the class size and length of the study lecture, as these factors will reduce student interaction and attention during the virtual lecture. Recent study found that interactivity increases attention span of learners in online learning (Geri, Winer \& Zaks, 2017). However, large class size and length lectures of Synchronous E-learning could negatively influence on the learning process, as Okereke et al. (2020) stated that E-learning platform limits the control of the instructors over their students who may log in but engage in other activities that are unrelated to learning. Interactivity is a vital component for refining the superiority of E-learning (Siemens, Gašević \& Dawson, 2015), but with big class size, teachers are more likely to adopt teacher-centered activities limiting students' interaction. Unfortunately, some applied colleges have issued a decree permitting the registration of 120 students in a single division instead of 40 students. Therefore, opportunities for student interaction with the teacher and with his colleagues are very scarce.

\subsection{Technical Challenges and Requirements}

There are many concerns among students regarding the technical problems associated with E-learning infrastructure (Eunice \& Cosmas, 2020). Therefore, they demanded a trial period to identify potential problems and address them before the start of the semester. Indeed, the applied colleges provided a trial period of two weeks before resuming the distance learning semester; this procedure helped students get acquainted with the educational platform as it is a completely new experience. The second requirement is to provide training courses for students so that they can learn how to deal with the platforms and use them effectively. This requirement is in line with many of the results of recent studies, as all of them recommend offering courses to students on an ongoing basis such as Al-Azawei et al. (2016), Aldowaj, Ghazal and Umar (2018) and Koçoğlu and Tekdal (2020). This explains the reason for the statistical differences between students who passed training courses on distance education and untrained students, as the trained students had better attitudes towards E-learning and were less afraid of educational and technical challenges than the untrained ones.

Furthermore, one of the most prominent challenges that students face is the user interface of the Moodle program, as they find it difficult to use it professionally or even practically. LMS programs appeared to be complicated for them and consume time and efforts in they use them, which could limit students' learning (Mpungose, 2020). Thus, the student does not prefer E-learning due to the complexity of the user interface, and this is what was reached in a recent study by Adnan and Anwar (2020), which indicated that students have negative attitudes about E-learning for several reasons, including the complex user interface. Poor internet connectivity is another issue raised by the interviewees because problems may occur (Eunice \& Cosmas, 2020) that prevent some students from attending the synchronized lecture, delaying the broadcast of live sessions, completing the exam, or submitting assignments on time. Thus, E-learning may lack equal opportunities for all students. when internet connectivity is weak or unavailable is certain areas, some students are unable to keep track of their counterparts who are in better-connected areas (Okereke et al., 2020; Alrashidi, 2017).

In such previous technical cases, the user refers to a specialized team that provides appropriate technical support. Therefore, students see that technical support is one of the priorities that must be secured. If the 
technical support services are poor and their response to urgent problems is slow or inadequate, students fall into many problems, especially at peak hours. Therefore, it is noted that a large number of studies confirm the importance of having a dedicated technical support team to treat distance education problems (e.g., Mishraa et al., 2020; Eunice \& Cosmas, 2020; Teymori \& Fardin, 2020).

\section{Conclusions and Recommendations}

The study recommends the necessity of continuously providing specialized training courses in the field of E-learning for students. And the provision of appropriate infrastructure to ensure the quality of distance education and to secure the educational and technical requirements. It is also imperative that the deanship of each of the five colleges develop appropriate plans and solutions to meet the challenges facing students. Therefore, the study also recommends training tutors on how to manage the virtual classroom, increase interaction, attract student attention, and apply effective evaluation methods.

Also, the study recommends future research to study the professors' attitudes towards E-learning as it is new experience in the Kuwaiti higher education context. Future research can investigate the faculty members challenges and requirements. This type of studies will provide higher educational institutions in the State of Kuwait with integrated results that help them improve the infrastructure and develop the E-learning process.

\section{Declaration of Conflicting Interests}

The authors declared no potential conflicts of interest concerning the research, authorship, and/or publication of this article.

\section{Funding}

This research is financed by the Kuwait foundation for the advancement of sciences KFAS (PN20-19T'T-03)

\section{References}

Adnan, M., \& Anwar, K. (2020). Online learning amid the COVID-19 pandemic: Students' perspectives. Journal of Pedagogical Sociology and Psychology, 2(2). https://doi.org/10.33902/JPSP.2020261309

Al-Azawei, A., Parslow, P., \& Lundqvist, K. (2016). Barriers and Opportunities of E-learning Implementation in Iraq: A Case of Public Universities. International Review of Research in Open and Distributed Learning, 17(5). https://doi.org/10.19173/irrodl.v17i5.2501

Al-Hunaiyyan, A., Alhajri, R.A., \& Al-Sharha, S. (2018). Perceptions and challenges of mobile learning in Kuwait. Journal of King Saud University - Computer and Information Sciences, 30(2), 279-289. https://doi.org/10.1016/j.jksuci.2016.12.001

AlAteeq, D.A., Aljhani, S., \& Eesa, D.A. (2020). Perceived stress among students in virtual classrooms during the COVID-19 outbreak in KSA. Journal of Taibah University Medical Sciences, 15(5), 398-403. https://doi.org/10.1016/j.jtumed.2020.07.004

Aldowaj, H., Ghazal, S., \& Umar, I. (2018). Instructors' Challenges In Implementing E-learning In A Public University In Yemen. The Turkish Online Journal of Design, Art and Communication, 1138-1146. https://doi.org/10.7456/1080SSE/155

Ali, G.E., \& Magalhaes, R. (2012). case studyBarriers to implementing e-learning: a Kuwaiti. International Journal of Training and Development, 13(1), 36-53. https://doi.org/10.1111/j.1468-2419.2007.00294.x

Alkharang, M.M. (2014). Factors that Influence the Adoption of e-Learning: An Empirical Study in Kuwait. Brunel University London. Available at: https://bura.brunel.ac.uk/bitstream/2438/11447/1/FulltextThesis.pdf 
Alkharang, M.M., \& Ghinea, G. (2013). E-learning in Higher Educational Institutions in Kuwait: Experiences and Challenges. International Journal of Advanced Computer Science and Applications, 4(4). https://doi.org/10.14569/IJACSA.2013.040401

Alrashidi, M. (2017). Investigating the e-readiness of subject supervisors to adopt E-learning in the State of Kuwait. University Of Southampton.

Arinto, P.B. (2016).Issues and challenges in open and distance e-learning: Perspectives from the Philippines. The International Review of Research in Open and Distributed Learning, 17(2). https://doi.org/10.19173/irrodl.v17i2.1913

Eunice, M.,\& Cosmas, M. (2020). An Analysis of Factors Affecting Utilisation of Moodle Learning Management System by Open and Distance Learning Students at the University of Eswatini. American Journal of SocialSciences and Humanities, 5(1): 17-32. https://doi.org/10.20448/801.51.17.32

Flick, U. (2009). An introduction to qualitative research. $4^{\text {th }}$ edition. London: SAGE Publication Ltd.

Geri, N., Winer, A., \& Zaks, B. (2017). A learning analytics approach for evaluating the impact of interactivity in online video lectures on the attention span of students. Interdisciplinary Journal of e-Skills and Lifelong Learning, 13, 215-228. https://doi.org/10.28945/3875

Koçoğlu, E., \& Tekdal, D. (2020). Analysis of distance education activities conducted during COVID-19 pandemic. Educational Research and Review, 15 (9), 536-543. https://doi.org/10.5897/ERR2020.4033

Mishraa, L., Guptab, T., \& Shreeb, A. (2020). Online teaching-learning in higher education during lockdown period of COVID-19 pandemic. International Journal of Educational Research Open, 10. https://doi.org/10.1016/j.ijedro.2020.100012

Mpungose, C.B. (2020). Emergent transition from face-to-face to online learning in a South African University in the context of the Coronavirus pandemic. Humanities and Social Sciences Communications volume, 7(113). https://doi.org/10.1057/s41599-020-00603-x

Murphy, M.P. (2020). COVID-19 and emergency eLearning: Consequences of the securitization of higher education for post-pandemic pedagogy. Journal of Contemporary Security Policy, 43(3).

https://doi.org/10.1080/13523260.2020.1761749

Okereke, M., Williams, A.E., Emmanuella, N.C., Ashinedu, N.U., \& Mairaj, M.W. (2020). COVID-19: challenges affecting the uptake of E-learning in pharmacy education in Africa. PanAfrican Medical Journal, 35(40). https://doi.org/10.11604/pamj.supp.2020.35.2.23910

Pallant, J. (2013). SPSS survival manual: A step by step guide to data analysis using IBM SPSS (4th ed.). Crows Nest, NSW: Allen \& Unwin.

Radnor, H. (2002). Researching your professional practice: doing interpretive research. Buckingham: Open University.

Siemens, G., Gašević, D., \& Dawson, S. (2015). Preparing for the digital university: A review of the history and current state of distance, blended, and online learning. Available at: http://linkresearchlab.org/preparingdigitaluniversity.pdf

Suryaman, M., Cahyono, Y., Muliansyah, D., Bustani, O., Suryani, P., \& Fahlevi, M. (2020). Covid-19 Pandemic And Home Online Learning System: Does It Affect The Quality Of Pharmacy School Learning? Systematic Reviews in Pharmacy, 11(8).

Teymori, A.N., \& Fardin, M.A. (2020). COVID-19 and Educational Challenges: A Review of the Benefits of Online Education. Annals of Military and Health Sciences Research, 8(3). 
Unger, S., \& Meiran, W. (2020). Student Attitudes Towards Online Education during the COVID-19 Viral Outbreak of 2020: Distance Learning in a Time of Social Distance. International Journal of Technology in Education and Science, 4(4), 256-266. https://doi.org/10.46328/ijtes.v4i4.107

Published by OmniaScience (www.omniascience.com)

Journal of Technology and Science Education, 2022 (www.jotse.org)

\section{(c) $\underset{\mathrm{BY}}{(\mathrm{i})}$}

Article's contents are provided on an Attribution-Non Commercial 4.0 Creative commons International License. Readers are allowed to copy, distribute and communicate article's contents, provided the author's and JOTSE journal's names are included. It must not be used for commercial purposes. To see the complete licence contents, please visit https://creativecommons.org/licenses/by-nc/4.0/. 